\title{
Globalization and Education: what future for the Maltese-speaking child?
}

\section{Antoinette Camilleri Grima}

\section{(2) OpenEdition \\ 1 Journals}

\section{Electronic version}

URL: http://journals.openedition.org/esp/2259

DOI: 10.4000/esp.2259

ISSN: 2532-0319

\section{Publisher}

Centre d'Information sur l'Éducation Bilingue et Plurilingue

\section{Printed version}

Date of publication: 1 June 2018

Number of pages: 31-43

ISSN: 1127-266X

\section{Electronic reference}

Antoinette Camilleri Grima, « Globalization and Education: what future for the Maltese-speaking child?

», Éducation et sociétés plurilingues [Online], 44 | 2018, Online since 08 February 2019, connection on

19 April 2019. URL : http://journals.openedition.org/esp/2259 ; DOI : 10.4000/esp.2259 


\section{GLOBALIZATION AND EDUCATION: WHAT FUTURE FOR THE MALTESE- SPEAKING CHILD?}

\section{Antoinette Gamilleri Grima}

Il presente documento sostiene che la globalizzazione porta cambiamenti per quanto riguarda l'uso delle lingue nell'ambito dell'istruzione che richiamano l'attenzione. A Malta, come in altri Paesi, l'inglese diventa sempre più frequente e importante ad ogni livello dell'istruzione ed è quindi possibile che stia producendo uno squilibrio nelle pratica bilingue del maltese e dell'inglese. Nelle scuole, a causa della presenza di allievi stranieri, si osservano segni del passaggio all'inglese come vettore dell'insegnamento a scapito del bambino parlante maltese. Inoltre l'accento posto in modo sempre più determinante sull'inglese nell'istruzione universitaria chiama a riflettere e ad agire in favore del maltese. A Malta il bilinguismo nell'istruzione è slato praticalo in modo spontaneo. Tuttavia questo documento, prendendo in considerazione le iniziative recenti per la promozione dell'inglese nell'istruzione universitaria, senza che si possano registrare simili iniziative per promuovere il maltese, preconizza diverse misure di pianificazione linguistica mirata.

Parole chiave: globalizzazione, diritti linguistici, istruzione, cambiamento linguistico, mantenimento e soiluppo della lingua, maltese

Le présent document affirme que les changements linguistiques dans le domaine scolaire apportés par la globalisation posent question. À Malte comme dans d'autres pays, l'anglais devient de plus en plus fréquent et important à tous les niveaux de l'éducation, et peut donc être en train de produire un déséquilibre dans le bilinguisme maltais-anglais. On constate des signes du passage à l'anglais comme vecteur de l'enseignement dans les écoles dû à la présence d'apprenants étrangers, au détriment de l'enfant qui parle maltais. En outre, l'accent placé de plus en plus sur l'anglais au niveau de l'éducation tertiaire appelle à la réflexion et à l'action en faveur du maltais. À Malte, le bilinguisme dans l'éducation a été pratiqué d'une façon spontanée. Prenant en considération les initiatives récentes pour la promotion de l'anglais dans l'éducation tertiaire, qui n'est pas compensé par des initiatives semblables pour le maltais, ce document préconise plusieurs mesures de planification linguistique ciblée.

Mots clés: globalisation, droits langagiers, éducation, changement linguistique, le maintien et le développement de la langue, maltais, éducation tertiaire.

\section{INTRODUCTION}

$\mathrm{T}$ This article presents an example of a context experiencing a growing tension in the field of education between the process of globalization on the one hand, and the sustained relevance of a local language as a medium of instruction in school and university on the other. In this paper I argue that 
Globalization and Education: what future for the Maltesespeaking child?

A. Camilleri Grima in those situations where English is taking over the roles previously held by local languages in education, the rights of the child to an education in their first language are being eroded. Language rights are here considered to be linguistic human rights or speakers' rights. That is, not only is the provision of education in the child's first language a necessary inclusive measure, but indeed a moral right.

In the literature on globalization and the English language there seem to be two main arguments. On the one hand, some linguists sustain that English is a killer language because it is bringing other languages into disuse while denying the users of these languages the right to develop their full human capabilities in their first language (e.g. Piller 2016; Phillipson 2017). On the other hand, other experts argue that English is the key to progress and economic development and it must therefore be enforced from primary school onwards for the benefit of the learner and their country. Furthermore, scholars like Blommaert (2010) postulate that it would be more appropriate to look at discourse rather than at language because the phenomenon of sociolinguistic globalization is a layered, complex process, evolving at a variety of scales. Blommaert (2010) argues that inequality has to do with modes of language use: how you speak a language, when you can speak it, and to whom, and therefore voice, not language, is what matters. I believe that it is very difficult to make generalizations or draw internationally applicable conclusions in the domain of language and globalization because each speech community is unique. One needs to embark on a careful analysis of the specificities of the historical, lexical and social realities of the context before making any claims about the benefits or the negative effects of English. In presenting the Maltese case, I will start by describing the societal and educational bilingualism prevalent in the country, and I will then present my argument from the point of view of the language rights of the Maltese-speaking citizen, in the light of a potential shift to English in the domain of education.

Malta is a small nation-state with its own national and official language, Maltese. Maltese is linguistically described as a mixed language, having developed over the centuries as a result of contact with the languages of the colonizers, namely Arabic, Sicilian, Italian and English. It is made up of a basic phonological, morphological and lexical core of Semitic structures and lexis; a super-stratum of Romance elements, namely a large stock of lexical, syntactic, phonological and some morphological accretions; and a much smaller English ad-stratum, consisting mainly of lexi- 
Globalization and Education: what future for the Maltesespeaking child?

A. Camilleri Grima cal material (for a detailed overview, see Brincat, 2006).

With regard to the status of Maltese as a national standard language, some of the main stages of progress were:

(i) In 1921, Maltese was allowed in parliamentary debates for the first time while Malta was under British rule;

(ii) From 1927 onwards legal deeds were written in Maltese;

(iii) In 1934, Maltese became official language next to English and Italian;

(iv) In 1964, Maltese was declared the national language, and coofficial with English in the Constitution of Independence from the British Grown, a status that was retained in the Constitution of the Republic of Malta in 1974;

(v) In 2004 Maltese became one of the official European Union (EU) languages upon Malta's accession to the EU.

With reference to corpus planning, some of the most important achievements are: a respected literary output in Maltese as of the beginning of the twentieth century; a standard orthography from the 1930 s, which has changed only slightly since then; the translation of the Bible into Maltese, first by Pietru Pawl Saydon (between 1929 and 1959) and then by the Malta Bible Society (published in 1984); a number of dictionaries, dating back to De Soldanis (around 1767) and Vassalli (published in 1796), and the more widely available publications of the twentieth century (e.g. the Maltese-English Dictionary by Psaila (1964); the MalteseMaltese ten volume dictionary by Serracino-Inglott (1975), and the six volume Maltese-English (1987)/English-Maltese dictionary by Aquilina (1999).

Maltese has co-existed for a long time in a diglossic relationship with important languages like Italian and English. In the twentieth century, Maltese became the national language of Malta, and has since then held co-official status with English. When Malta became a member state of the EU, the Maltese language and its speakers began to enjoy the benefits associated with such status, most importantly a new translation and interpretation industry accompanied by desirable jobs in the EU institutions. The translation of EU documents into Maltese, and the participation of Maltese officials in the EU significantly enhanced the range of topics being written and spoken about in Maltese, including the elaboration of the technical and scientific registers.

According to the latest Census of Population and Housing (National Statistics Office 2014), 90\% of respondents living in Malta claimed to speak Maltese very well, and 78\% of the same group of respondents claimed to speak English very well. 
Globalization and Education: what future for the Maltesespeaking child?

A. Camilleri Grima

EDUCATIONAL BILINGUALISM IN MALTESE AND ENGLISH
Therefore, about $80 \%$ of the population can be considered to be bilingual in Maltese and English. Generally speaking, the Maltese bilingual person learns two languages from infancy, and uses both languages in most situations as circumstances demand. Maltese is undoubtedly the first language of the vast majority of Maltese, who are undeniable exposed to English on a daily basis through the media and within society at large. Maltese predominates as a spoken medium in government administration, including Parliament and the Law Courts, but much written official and non-official correspondence takes place in English. In the print media, two of the 5 daily newspapers and five of the 11 weeklies are in English - the rest are in Maltese. Online news media are popular in both languages: the political groups publish in Maltese and attract an important readership, but local online papers in English probably have a more significant following, with a considerable overlap among readers who access both the Maltese and English papers online. The Gazzetta tal-Gvern ta' Malta / The Malta Government Gazette is bilingual with a juxtaposition of information in Maltese and English (but the titles in Maltese are much more prominent).

English has undoubtedly been crucial in Malta's economic development. Malta has no natural resources except for a Mediterranean climate, which, together with a great historical heritage and a sense of entrepreneurship, continues to help maximize Malta's income on the basis of the tourist industry. More recently Malta became attractive to the finance industry. At the same time IT services and I-gaming companies have mushroomed, employing local and foreign workers while boosting Malta's real estate.

The advantage of this social, bilingual reality is that so far, it has been additive. No doubt, the education system has helped maintain a level of balanced bilingualism, as explained below.

The English language was introduced in the Maltese education system when Malta was under British rule (1800-1964) and further gained importance in recent years as an international language of communication. At roughly the same time that the teaching of the English language spread in all Maltese schools, the Maltese language became an entry requirement to the University of Malta (in 1945), and for decades schools have been obliged to teach Maltese as a subject in order to obtain a license to operate. More importantly, Maltese is a relevant medium of instruction across subjects. Although reading and writing generally take place 
Globalization and Education: what future for the Maltesespeaking child?

A. Camilleri Grima in English, Maltese is used profusely in spoken interaction.

The Maltese bilingual education system can be described as strong because it promotes high levels of bi/plurilingualism for all participants in the program. Bilingualism pertains to all levels of schooling, from early childhood to post-secondary; it is practiced in all schools, albeit to varying degrees. Throughout the system, spontaneous and intentional use of Maltese and English is frequent among teachers and learners and school administrators. As a system, this evolved naturally as a result of interaction between bilingual teachers and bilingual learners who mostly speak in Maltese, but read and write in English. Farrugia (2017) aptly illustrates codeswitching in Maltese classrooms by providing examples from mathematics lessons. Her research findings are similar to other research output based on classroom discourse that has been carried out over the last thirty years. Research basically confirms the efficient and effective use of two languages as medium of instruction across the curriculum.

In the national $16+$ examinations, which serve as the gateway to post-secondary education, candidates are allowed to answer questions in either Maltese or English in some subjects, namely, Religious Instruction, History, Environmental Studies, and Social Studies. In the matriculation exams prior to entry to university, European Studies and Systems of Knowledge are added to this list. At university level, students of medicine who have not obtained a pass in the national examination are required to have a qualification in Medical Maltese in order to be allowed to study and to practice. Students of law are also obliged to have 'Advanced' level passes in Maltese and English. For the past thirteen years, students studying to become primary school teachers were expected to be in possession of a pass in the Maltese and English proficiency tests organized by the Department of Education. As of the 2017-2018 academic year, proficiency courses in Maltese and English became mandatory for student-teachers who would not have obtained a high grade in the matriculation exams.

The 2012 national curricular document (Ministry for Education and Employment, 2012) encourages schools to reflect on their own language policy. This document refers to Maltese and English as the core languages, and gives importance to bilingualism in education by highlighting the need for the simultaneous development of these two languages. Furthermore, in the "Language Policy for the Early Years in Malta and Gozo" (Ministry for Education and Employment 2016) it is stated that: 
Globalization and Education: what future for the Maltesespeaking child?

A. Camilleri Grima
(1) Maltese and English are the languages of schooling;

(2) All children should have the opportunity to develop these two languages;

(3) Educators should be fluent in both, and impart positive attitudes toward both languages; and

(4) Educators can adopt language mediation, i.e. switching languages in order to facilitate comprehension and communication.

The 2016 language policy for the early years is undoubtedly a step in the right direction, even if it is as yet unknown to what extent and how it is being implemented. As with every policy document, implementation is crucial. For instance, with reference to the 1999 national curriculum which dictated an English-only medium for most subjects without codeswitching, we find that in those schools where this policy was implemented it had a potential negative effect on the Maltese-speaking child. Indeed, Farrugia (2009: 21) noticed "the discomfort of some pupils" who "held back from asking questions because they were afraid that they would make mistakes or because they were not sure how to ask the question in English".

Similarly, Zerafa (2016) reports on a study intended to gain insight into whether language (Maltese or English) has an impact on the Maltese child's ability to solve arithmetic word problems (age 7-8). Zerafa concluded that pupils found word problems more challenging than non-verbal computations, presumably due to the language component. Moreover, "when problems were in their first language they [the children] understood and recalled them better, as well as solved them using the correct operations. They also managed to do so quicker" (Zerafa 2016: 201).

Other research results tally with those of Farrugia and Zerafa. Ventura (2016) reviewed a number of studies that analyzed the effect of language in the Maltese science classroom. In science, only English is used for reading and writing purposes. Ventura (2016: 249) concluded that "all the studies under review support the hypothesis that the language of assessment has a variable effect on performance in science tests and examinations depending on the students' ability in the language". For example, weaker learners fared better in a science test given in Maltese in their first year of secondary school when compared to their performance on the test in English. Even at sixth form level (age 16-18), among students who achieve highly in science, there are some who need support to overcome the linguistic challenges posed by the scientific register in English (Ventura, 2016). Ventura (2016) thinks that if candidates were allowed to answer in Maltese and to 
Globalization and Education: what future for the Maltesespeaking child?

A. Camilleri Grima

THE CHALLENGES OF GLOBALIZATION IN MALTESE EDUCATION codeswitch in their examination answers, this would increase the validity of science examinations as it would be a better reflection of the candidates' true knowledge of the subject.

In Camilleri Grima (2013) I review the pedagogical functions of codeswitching between Maltese and English in classroom discourse. There are a number of legitimate reasons why teachers and learners use all their linguistic resources in classroom interaction, such as the explanation of subject content, and learner participation. The teacher switches from English to Maltese, and uses a mixed code, to make sure that the learners can make sense of the subject matter. As Lemke (1989: 136) explains, in order to comprehend a text we need "to be able to paraphrase it, restate it in our own words, and translate its meanings into the more comfortable patterns of spoken language".

Research in Maltese classrooms has provided us with enough evidence to back the continued use of the Maltese language and of codeswitching, as a medium of instruction. If the Maltese-speaking child is immersed in an English-only school environment they will definitely be at a disadvantage, and in danger of educational disengagement. The evidence presented by Farrugia (2009), Zerafa (2016) and Ventura (2016) clearly shows that the exclusive use of English is detrimental to the Maltese-speaking part of the student population. Furthermore, the Council of Europe's Malta Policy Profile (2015: 12) states that "the incidence of English language use is consistently higher among the managerial and professional classes". Thus, children coming from the lower social classes are more likely to be speakers of Maltese. Therefore, I maintain that it is absolutely necessary for Maltese-speaking children to have access to education through Maltese, alongside English.

This leads me to the new challenge that our education system is facing and that could potentially undermine the current context of positive bilingualism. I posit that Maltese is beginning to experience the negative aspect of internationalization in education. Notwithstanding the vitality of the Maltese language in society, in the domain of education there are some worrisome signs as I will now explain.

Globalization is described by Marlina (2013: 1) as "porous geographical boundaries allowing ideas, people, services and goods to move rapidly across borders". The effects of globalization can be examined from a number of perspectives, such as the linguistic, economic, social and political. From the linguistic point of view, 
Globalization and Education: what future for the Maltesespeaking child?

A. Camilleri Grima globalization seems to have empowered speakers of English, irrespective of whether they are native speakers or have learned English as a second or foreign language. As a result, governments and schools all over the world are emphasizing the teaching and learning of English, possibly to the detriment of other languages. Such decisions are not necessarily always to the benefit of language users, nor of the economy they purport to support. Schuftan (2018) blames globalization for the deterioration of human rights and because it enriches the already well-off few at the expense of improving the life of the many have-nots. Similarly, Romaine (2015) and Piller (2016) describe situations where the fast shift to Englishmedium education is having very undesirable consequences such as educational failure and lifelong repercussions with considerable cost to the economy and to future generations.

This article highlights one effect of globalization on language use in education essentially deriving from the rapid movement of people across borders. In fact, as long as learners in Maltese classrooms were all Maltese, there seemed to be no difficulty in concurring with a bilingual medium of instruction because the use of English was not perceived as a threat to Maltese. On the contrary, Maltese held a rightful place as a medium of instruction and served as a scaffold to the learning of English. However, as a consequence of the presence of an increasing number of newly arriving non-Maltese children in schools, we are experiencing a switch to an English-only medium of instruction. When non-Maltese children are in class, teachers tend to use English only, without providing learners with an explanation of the subject in Maltese, and in the meantime also ignoring the pedagogical functions of codeswitching, because they assume that the Maltese children are able to follow the lesson in English, while the non-Maltese would not be able to understand any Maltese.

From a school experience project carried out by twelve post-graduate students of education during scholastic year 2016-17, it was found that in four out of the twelve state schools observed, English was used exclusively when non-Maltese learners were present in the classroom. This challenges the perception that bilingualism in education is still the norm, and alerts us to the possibility that the Maltese education system might be slowly resorting to an Englishonly medium. The problems arising from this shift relate to the rights of the Maltese-speaking child to participate fully in their education. There can be no doubt that education is one of the most decisive factors in determining the life chances and human development of the child. In fact, choice of language as medium of instruction is one of the most important factors leading to their success or 
Globalization and Education: what future for the Maltesespeaking child?

A. Camilleri Grima

EMPOWERING

THE MALTESE

LANGUAGE

AND ITS USERS to their exclusion. In the previous section I explained how research studies in Malta support this claim, and how bilingualism in education functions in the Maltese context. In brief, implementing an English-only policy in education cannot be morally justified once it interferes with learning the mother-tongue, or the other subject knowledge which can be at risk if the medium of instruction (English) acts as a barrier rather than a medium.

In parallel to the situation witnessed in schools, the University of Malta is strongly emphasizing the English proficiency of its students. It is obliging undergraduate students to follow up to 12 ECTS (European Credit Transfer System) worth of study-units in English, in addition to their normal course requirements, in order to equip them with an enhanced competence in the English language. Unfortunately, there is no equivalent effort to support proficiency levels in Maltese.

When English takes over as a result of internationalization to the detriment of local languages, then the diversity of language knowledge will no longer be sustained, let alone enhanced. As Piller (2016) explains, "the other side of the equation between English and academic excellence is the devaluation of knowledge researched and disseminated in languages other than English". This has two important consequences: (i) The loss of linguistic diversity which is a serious loss of cultural diversity, arguably equivalent to that of environmental impoverishment, from which mankind as a whole will suffer $(e . g$. the non-market values of a language related to issues like identity, and the enjoyment of literature and other cultural products in one's own language); and (ii) the heavy cost of acquiring proficiency in a foreign language while losing self-respect with the likelihood that a local variety of English, distant from the native model or with at least a good level of international intelligibility, will develop anyway (Van Parijs 2015; Piller 2016; Ricento 2015).

In order to retain positive bilingualism in Malta, the support for languages needs to be balanced. Therefore, I will now consider some language policy proposals in the hope that internationalization through English will not undermine the positive advantages of bilingualism in Maltese education.

Wiley and Garcia (2016) draw attention to the fact that prestige is a crucial element in sustainable language use. They argue that while status planning is focused on the language itself, the status of a language has implications for its speakers. Conversely, the status of the speakers may also have implications for the language variety spoken. In the domain of education, prestige is accorded 
Globalization and Education: what future for the Maltesespeaking child?

A. Camilleri Grima on two counts: (i) the attitudes/status of the subject-matter that is dealt with in a particular language, and (ii) the status of the users of a particular language. McColl Millar (2005) uses the metaphor of a cline (continuum or gradation) to describe how using a particular language in certain domains gives it, and its speakers, the relevant status. According to McColl Millar (2005) the cline starts with use of a language in local contexts at a linguistic level described as 'folk' or non-literary, to the next stage when a language is used in the humanities in 'elevated' style, to the top level where a language is used for scientific and technical purposes in research. The 'elevated' style would also be used in the media, in drama and in schools. The use of a language in research then implies that the language is used at university level, for scholarly articles associated with science and technology.

It is pertinent to ask: to what extent is the Maltese language being allowed to flourish at the top level of research, and what status is accorded to those university students and academics who write and publish in Maltese? Indeed, while Maltese is flourishing in an elevated style in the literary field, and is used on a daily basis in politics, in the law courts, in parliament and in the media, the same cannot be said for schools and in particular with reference to the University of Malta. Few dissertations are written in Maltese and the $\mathrm{PhD}$ regulations are clear: English must be used except for a thesis in areas of study involving a language that may be written in that language. The obstacle to using Maltese in university level research seems to run counter to the designation of Maltese as an EU official language and the right to use it in all domains, including the technical and scientific ones.

In brief, I recommend the following policy measures in order to safeguard (i) the continuation of bilingualism; (ii) the right of the Maltesespeaking child to access education at all levels through their first language; and (ii) full respect for Maltese as one of the EU official languages:

1. Continue to use both Maltese and English as a bilingual medium of instruction. Both the Maltese language and codeswitching are to be acknowledged as pedagogical resources, essential for the inclusion of the Maltese speaking child. Research has proved that codeswitching serves fundamental purposes like participation in learning events, the explanation of subject matter and for establishing a rapport between learners and teachers. At the same time, English continues to serve as a crucial link to the world and an open door to furthering knowledge. Codeswitching is an inclusive measure for both the Maltese and the non-Maltese speaking learner.

2. Increase efforts in the teaching of Maltese as a foreign language (FL) at all 
Globalization and Education: what future for the Maltesespeaking child?

A. Camilleri Grima
CONCLUSION education levels, including in adult education. The knowledge of Maltese by the non-Maltese speaking learner will ascertain the continued use of Maltese by the Maltese learners and their teachers without feeling guilty that they might be shutting out their non-Maltese peers. Initiatives could include: more teachers and lessons dedicated to the teaching of Maltese as a FL at all school levels; the provision of more teaching materials and the creation of national examinations in Maltese as a FL. The non-Maltese learner will, in this way, acquire enough proficiency to be able to participate in all the (bilingual) lessons, and for adults to feel included in the Maltese culture and society at large.

3. Rule that all student-teachers and teachers should be bilingual in Maltese and English, and offer courses in Maltese as a FL to non-Maltese teachers who are normally employed on temporary contracts. For education in Malta to continue to be bilingual, and thus inclusive, it is essential for every teacher to be fluent in at least these two languages. Non-Maltese teachers must be obliged to learn Maltese in order to safeguard the inclusion of the Maltese-speaking learners in the lesson, for example, when they ask questions or require further explanation.

4. Provide courses in Maltese proficiency for all students at university. Furthermore, the use of Maltese in professional courses and especially in the writing of a thesis from undergraduate to post-doctoral level should be encouraged. This would ensure that the Maltese language is retained as a linguistic and cultural capital and be considered at a par with other official EU languages.

5. Visiting students at the University of Malta are already offered the option to learn Maltese as a FL, and it is only right for non-Maltese staff to also be given opportunities to learn Maltese as a FL as part of their continued professional development. A basic knowledge of Maltese would avoid the embarrassment of university staff who, for instance, are unable to respond to simple queries in Maltese.

I have argued that the Maltese speaking child, and the student at the University of Malta have a linguistic right to an education which respects the Maltese language. Indeed, linguistic rights are inseparable from other human rights and are interdependent with other rights, such as the right to the freedom of expression (opinions are expressed in a language), to development (through an education that respects the child's language) and self-determination (the right to make one's own choices, including choice of language). UNESCO's Universal Declaration on Cultural Diversity (Article 5) makes it clear that "all persons should therefore be able to express themselves and to create and disseminate their work in the language of their choice, and particularly in their mother-tongue". 
Globalization and Education: what future for the Maltesespeaking child?

A. Camilleri Grima

\section{REFERENGES}

It is my firm belief that the school and the university can best promote and sustain the education of Maltese children and adults by better respecting the use of the Maltese language, because this gives them the best possibility of realizing the full range of their human capabilities. Besides, there is no doubt that bilingualism delivers clear cognitive, cultural and affective benefits to children and to their communities, and a shift to English-only would be detrimental. If Maltese is sidelined, then we might end up with the linguistic dispossession of Maltese. Which way do the Maltese education authorities wish to go?

BLOMMAERT, J. 2010. The Sociolinguistics of Globalization. Cambridge: Cambridge University Press.

BRINCAT, J. M. 2006. Languages in Malta and the Maltese Language. Éducation et Sociétés Plurilingues, 20: 7-18.

CAMILLERI GRIMA, A. 2013. A select review of bilingualism in education in Malta, International Journal of Bilingual Education and Bilingualism, 16(5): 553-569.

COUNCIL OF EUROPE, 2015. Language Education Policy Profile 2015. Malta; Ministry of Education and Employment.

FARRUGIA, M.T. 2009. Registers for mathematics classrooms in Malta: Considering options. For the Learning of Mathematics, 29(1): 20-25.

FARRUGIA, M.T. 2017. Bilingual classrooms in Malta: teaching Mathematics content and language. Éducation et Sociétés Plurilingues, 42: 61-72.

LEMKE, J.L. 1989. Making text talk. Theory into Practice XXVIII(2): 136-141.

MARLINA, R. 2013. Globalization, internationalisation and language education: an academic program for global citizens. Multilingual Education, 3(1): 1-21.

McGOLL MILLAR, R. 2005. Language, Nation and Power. London: Palgrave Macmillan.

MINISTRY FOR EDUCATION AND EMPLOYMENT, 2012. A National Curriculum Framework for All. Floriana: Malta.

MINISTRY FOR EDUCATION AND EMPLOYMENT, 2016. A Language Policy for the Early Years in Malta and Gozo. Floriana: Malta.

NATIONAL STATISTICS OFFICE, 2014. Census of Population and Housing 2011. Valletta: Malta.

PHILLIPSON, R. 2017. Myths and realities of 'global' English. Language Policy, 16(3): 313-331.

PILLER, I. 2016. Linguistic Diversity and Social Justice. Oxford: 
Globalization and Education: what future for the Maltesespeaking child?

A. Camilleri Grima
Oxford University Press.

RICENTO, T. Ed. 2015. Language Policy and Political Economy. Oxford: Oxford University Press.

ROMAINE, S. 2015. Linguistic Diversity and Global English: The Pushmi-Pullyu of Language Policy and Political Economy, in T. Ricento (ed.) Language Policy and Political Economy. Oxford: Oxford University Press, pp. 252-275.

SCHUFTAN, C. 2018. The view from orthodoxy: Point/Counterpoint on gloabalization and human rights, International Foumal of Health Services, 0(0): 1-6.

VAN PARIJS, P. 2015. The ground floor of the world: on the socioeconomic consequences of linguistic globalization. In Ricento, T. (ed.) Language Policy and Political Economy. Oxford: Oxford University Press, pp 231-251.

VENTURA, F. 2016. Language and achievement in science in a bilingual context: a Maltese perspective. Malta Review of Educational Research, Special Issue on Bilingualism in Education in Malta, 10(2): 241252.

WILEY, T.G. \& GARCIA, O. 2016. Language Policy and Planning in Language Education: Legacies, Consequences, and Possibilities. The Modern Language Fournal, 100:48-63.

ZERAFA, E. 2016. Language influence on solving arithmetic word problems. Malta Review of Educational Research, Special Issue on Bilingualism in Education in Malta, 10(2): 201-222. 